simple comparison of positions at the extreme limits of time. It is not made clear why observations at intermediate dates, such as those of the Radcliffe Observatory, have not been used. The plan adopted seems the more strange, since the precessional variation has been applied and a comparison has been instituted. Considering the important part these proper motions were to play in the subsequent discussion, it would seem that too much care could not be exercised in their determination. These proper motions have been arranged in tables according to their amount, or the magnitude of the stars, or the character of spectrum, and, indeed, in every way that ingenuity could suggest as likely to be useful. This method of distribution cannot but be of essential service to those who wish to make further use of the material.

Next we have a determination of the precessional constants. The final result may not possess more than an academic interest, but the research is thorough and valuable. It would serve no useful purpose to enter into details, since those who are interested in such recondite questions must refer to the original sources for information, but the numerical results may be quoted, since they differ from Newcomb's values by a greater amount than would have been anticipated. For the centennial values of $m$ and $n$ we have :-

$$
\begin{array}{lcccccccc}
\text { Newcomb } & \ldots & \ldots & \ldots & & \ldots & 4607^{\prime \prime} \cdot 1 \text { I } & \ldots & 2005^{\prime \prime} \cdot \text { II } \\
\text { Dyson and } & \text { Thackeray } & \ldots & 4607^{\prime \prime} \cdot 57 & \ldots & 2005^{\prime \prime} \cdot 31
\end{array}
$$

Another result which follows incidentally from the method of discussion is to show that, so far as this material is available, there is no reason to suspect any rotation of the brighter stars, as a whole, relatively to the fainter stars.

Lastly, the authors assign a direction to the solar motion, or rather many directions, for the material is discussed in many ways, all interesting. Here, again, we must content ourselves with the final result, which places the apex of the sun's motion in right ascension $275^{\circ}$ and north declination $37^{\circ}$, referred, presumably, to the equinox of $185^{\circ}$.

In tendering our congratulations to Messrs. Dyson and Thackeray, and all who have been engaged in this work, we cannot help remarking that, as in the past, the Royal Observatory has distinguished itself by its energy in laboriously piling up observations, so in this instance, it demonstrates equally happily its power to make the accumulated material available for the advance of philosophical astronomy.

The title of the second book reminds us how loyally the Greenwich Observatory has served the purposes of its foundation. To determine, or to supply the means for determining, the longitude has constantly figured in its programme of work. The times have altered, the conditions of the problem have changed, and, above all, accuracy has increased, but, steadfast to its original design, the Royal Observatory has always been willing to assist in such inquiries, whether in the interests of navigation or for the purposes of geodesy. The Paris meridian seems to have been a constant source of anxiety to Greenwich, and the present volume gives the history of no less than three attempts to grapple with the difficulty. The two earlier results, 9m. 20.85s. and 9m. 20.79s. west of Greenwich, seem fairly accordant to the lay mind, but since they both differed in the same direction from the results of the French observers, the small discrepancy led to a third attempt in 1902, from which it appeared that Paris was west of Greenwich $9 \mathrm{~m}$. 20.932s., with a probable error of only $0.006 \mathrm{~s}$. Since this probable error is equivalent to about the length of an ordinary writing table, it would seem to possess the necessary accuracy, and the problem of the distance between the meridians of Greenwich and Paris may be considered as laid aside for some time to come. The remaining portion of the book is concerned with the longitudes of Montreal, Waterville, and Canso, and of stations incidentally connected with the scheme of operations. The result is to place Montreal in west longitude $4 \mathrm{~h} .54 \mathrm{~m}$. $18.62 \mathrm{~s}$, with an uncertainty of about 20 feet. Doubtless the day will come when this error will be felt to be intolerable, but if a demand is made for a fresh inquiry, we may be sure that the best traditions of Greenwich will respond to the appeal.

No. I 908 , VOL. 74$]$

\section{ANTI-TYPHOID VACCINE.}

A MEMOIR "On the Standardisation of Anti-typhoid Vaccine," by Captain George Lamb and Captain W. B. C. Forster, has just appeared (Scientific Memoirs of the Government of India, No. 2I. Calcutta: The Grovernment Printing Office, 1906. Pp. 15. Price $7 d$. .). After reviewing the various methods which have been proposed for the standardisation of Wright's anti-typhoid vaccine, Captains Lamb and Forster come to the conclusion that the virulence of the organisms used in the preparation of the vaccines must be taken into account. Since it appears that virulence is in direct proportion to the number, or avidity for immune body, of the receptors, an estimation of these latter in any vaccine will take cognisance of the virulence of the organism from which it was prepared. Admitting this as a basis, the method of standardisation suggested by Captains Lamb and Forster is to estimate what dilution of the various vaccines when mixed in equal parts with serum is able to remove completely the bactericidal power of that serum; in other words, to determine in what dilution of vaccine the receptors completely neutralise the amboceptor content of the serum. This is carried out by preparing a number of different dilutions of the vaccine, which are each mixed with the same amount (Ioo c.cm.) of fresh goat serum, and left in contact for an hour at $37^{\circ} \mathrm{C}$. At the end of this period a small quantum of living typhoid culture is added to each tube, the several tubes are incubated for about twenty-four hours, and then sterile broth is added to each tube in order to ascertain whether the bacilli have been killed or no, and in this way various vaccines may be compared. The memoir must be consulted for the details of the method. R. T. HewLETt.

\section{UNIVERSITY AND EDUCATIONAL} INTELLIGENCE.

OxFORD.-The thirteenth " Robert Boyle" lecture of the Junior Scientific Club will be delivered by Prof. J. H. Poynting, F.R.S., on Wednesday, May zo, upon the subject of "The Pressure of Light."

Mr. J. S. C. Douglas, Christ Church, has been elected to the Radcliffe travelling fellowship for 1906.

Prof. Ritchie, fellow of New College, has been nominated as an examiner in preventive medicine for 1906,1907 , and I 908 .

The 284th meeting of the Junior Scientific Club was held on May 16 , when Mr. P. W. Robertson read a paper on "A New Method of Estimating Quinine," and Prof. E. G. Hill one on "Chemistry in India."

Cambridge.-The museums and lecture rooms syndicate has reported that the chemical laboratory of Gonville and Caius College will be closed at the end of the academic year 1906-7. It will therefore be necessary to provide further accommodation in the University for the students who have hitherto found places in the chemical laboratory. The museums and lecture rooms syndicate recommends that a site in the museums' grounds contiguous to the buildings of medicine should be set apart for this purpose. It is also recommended that the proposed extension of the Cavendish Laboratory should take place on a site with a frontage to Free School Lane to the north of the existing building. Lord Rayleigh's gift of $5000 l$. of the Nobel prize will, it is hoped, enable this building shortly to be begun.

The Vice-Chancellor has been authorised to convey to the Worshipful Company of Goldsmiths the thanks of the University for its munificent gift of 50ool., to be applied to the present needs of the University library.

The well-known authority on coral reefs and oceanography, Mr. J. Stanley Gardiner, has been nominated by the master and fellows of Gonville and Caius College to be pro-proctor for the ensuing year.

Dr. Bonney will lecture at 5 p.m. on Thursday, May $3 \mathrm{I}$, in the Sedgwick Museum, on "Volcanoes and Man's Experience of them."

Steps are being taken for the provision of a permanent endowment to place the Balfour library in a secure position. The library owes its origin to the generosity of the family of the late Prof. F. M. Balfour, who after his death in I 882 presented his scientific books to the University for the 
use of the zoological laboratory. The library so constituted was housed in a room adjacent to the laboratory, and has ever since been freely open to all members of the University and to others qualified to make use of it. The library has been maintained hitherto out of the fees paid by students attending the classes; and the burden which it thus places upon the resources of the laboratory is undesirable. A committee has therefore been formed for the purpose of collecting subscriptions, and of establishing a fund to be called the Balfour Library Endowment Fund, with the object of putting the library on a secure and satisfactory basis. The committee at its first meeting agreed that the fund, when established, "be offered to the University at such time and under such conditions as the subscribers shall hereafter determine, provided that the management be closely connected with the zoological laboratory, and that the library be freely open to students." Subscriptions may be paid to the Balfour Library Endowment Fund, at Messrs. Barclay's Bank, or to the treasurer, Mr. Adam Sedgwick, Zoological Laboratory, New Museums, Cambridge. The sum already received or promised amounts to about $500 l$.

THE King and Queen will visit Newcastle on July II to open the new wing that completes the Armstrong College. The King will also open the new university buildings at Aberdeen on September 24 .

IT has been resolved by the Corporation of McGill University, Montreal, to confer the honorary degree of LL.D. on Dr. D. Macalister, president of the General Medical Council of the United Kingdom.

IT is announced from the Agricultural Department of the University of Edinburgh that Mr. E. Thompstone has been appointed assistant deputy director of agriculture for Bombay Presidency, and Mr. Roger Prosser will go to La Germania, Argentina, to investigate salt soils.

THERE is a vacancy for a junior assistant secretary, holding a science degree or possessing equivalent qualifications, in the office of the department of technology of the City and Guilds of London Institute. Applicants for the appointment should communicate with the superintendent, Exhibition Road, London, S.W.

ACCORDING to the Chemiker Zeitung, the University of Basle has fallen into line with the German universities, and now requires from all German doctor candidates the leaving certificate of a nine-year gymnasium or of a corresponding Swiss institution. The German Government had threatened not to recognise the doctor's degree if the University continued to grant it on the old conditions.

A GENERAL meeting of old students of the Technical College, Finsbury, was held on May 8 to discuss the proposal to form an Old Students' Association. In a short opening speech Sir Owen Roberts, who occupied the chair, expressed his approval of such associations, and said that it gave him great pleasure to preside at the organisation meeting of such a one as this promises to be. Dr. M. O. Forster, F.R.S., was elected president of the association.

IT is announced in Science that Mr. Andrew Carnegie has made a donation of $20,000 l$. to Lehigh University; and that the movement to increase the endowment of Victoria University, Toronto, by $60,000 l$. is now practically completed. The amount has been raised all but $2400 l$., counting the $10,000 l$. given by $\mathrm{Mr}$. Carnegie. The latter gift was conditional upon the raising of an additional ro, oool., but no trouble in fulfilling the condition is expected. According to the N.Y. Evening Post Sir William McDonald, of Montreal, has given $11,000 l$. for the purpose of erecting an extension to Prince of Wales College, Charlottetown, P.E.I. Additional facilities will be provided for teaching nature-study, domestic science and kindred subjects, and for training teachers.

THE commission appointed by the German Association of Naturalists and Physicians at Breslau in 1904 to consider the mathematical and scientific instruction in German schools held a general meeting in Elberfeld on April 9-II, and discussed the following questions at length:- the syllabus of the mathematical and scientific teaching in the girls' high schools, in the six-class Realschulen and in the Reformschulen; the science teaching of the elementary and continuation schools, as well as that of the commercial and special schools; certain hygienic and sexual questions in connection with school life; the chemical instruction given in the training colleges. While the results and reports of these discussions will be laid before the society at the Stuttgart meeting in the autumn, it has been decided to issue a report on the form of instruction recommended for the girls' high schools as early as possible.

AN addition to the many proofs which have reached us of the active interest taken on the Continent in the reform of mathematical teaching is afforded by the publication of a German translation of the address delivered to the Mathesis Society by Prof. Gino Loria on April 22, 1905, at Milan. The translation, which is literal, has been made by Dr. H. Wieleitner, and is published by G. J. Göschen, of Leipzig, under the title of "Vergangene und künftige Lehrpläne." The address affords evidence of a general tendency on the Continent to attach less importance in school curricula to the performance of gymnastic exercises of little educational value, and to introduce the wider ideas of higher mathematics at an earlier stage in the curricula. The object of mathematical teaching should be to give the pupils as wide an insight into mathematical methods, especially higher methods, as is consistent with thoroughness. It is impossible to study a paper like this without seeing how much better off in this respect our Continental rivals are than we are. This difference is due partly to the fact that under our university systems a large proportion of the mathematical teachers of our schools never learn any higher mathematics whatever, whereas in Germany or Italy every student has the opportunity of studying under specialists. A second cause of difference is due to the lesser importance attached on the Continent to examinations and syllabuses. In illustration of the spirit of the paper, Prof. Gino Loria considers that " elementary conics " is of little value as usually studied, as the subject contains no new ideas, and the pupils are only wearied with complicated exercises. This is certainly true of the subject as commonly taught, but, at the same time, a course of elementary mathematics ought to contain some introduction, however small, to the study of common curves, their tangents, and their other simpler properties treated geometrically and not as graphs.

THE conditions of admission of students to college not only vary in different countries, but also of ten in the colleges and universities of the same country. This subject is receiving interested attention among educationists in the United States. Science for April 27 prints an address by President G. E. MacLean, of the State University of Iowa which discusses the question: Can there be a coordination of the examining, certificate, and accrediting (including school inspection) systems for admission to college, looking toward a common or national administration in the interests of students, colleges, and the preservation of standards? The American procedure in this matter is not uniform. The western plan may be said to be the admission of students to colleges and universities by certificates from duly inspected secondary schools, while in eastern States the method is to admit only by examinations conducted by representative boards or otherwise. Some valuable opinions are collected in the address as to the relative value of the two courses. President MacLean says that the accrediting system has raised the standard of the work done. It has linked the secondary school into one system with the college. It has given an increase of students entering college, and with better average preparation. It is sometimes alleged that the scholarship of students admitted on certificate is lower than that of students who are required to pass examinations, but President Schurman, of Cornell, says the experience at his university does not support the contention. On the other hand, Prof. Hadley, of Yale, believes that the examination method is fairer to boys who come from a distance to the university. Yet, with the exception of Harvard, Yale, and Princeton, practically a coordination of the examining, certificate, and accrediting system has been reached inasmuch as testimonials issued by the college authorities are interchangeable. President MacLean concludes by urging the need for liberty to each institution, and records his belief that it is a question of evolution-the best system or combination of systems will survive.

NO. I 908, VOL. 74] 